\title{
RESEARCH
}

Open Access

\section{Impacts of fire severity and cattle grazing on early plant dynamics in old-growth Araucaria-Nothofagus forests}

\author{
Paola Arroyo-Vargas ${ }^{1,2}$, Andres Fuentes-Ramírez ${ }^{1,3,4^{*}}$ (D), Bart Muys ${ }^{5}$ and Aníbal Pauchard ${ }^{4,6}$
}

\begin{abstract}
Background: Fire has historically shaped the dynamics of Araucaria araucana-Nothofagus pumilio forests in the Andean region of South America. Nevertheless, human disturbances and stronger drought events have resulted in increased occurrence and severity of wildfires. Regardless of their conservation relevance, the initial response to fire of Araucaria-Nothofagus forests has not been well documented. Through this research we tested the hypothesis that plant composition of Araucaria-Nothofagus forest after fire will initially differ in its recovery depending on fire severity, but over time, plant similarity will increase among areas with different levels of fire severity. The study was carried out in old-growth Araucaria-Nothofagus forests in south-central Chile $\left(38^{\circ} \mathrm{S}\right)$ that were burned in 2015. We studied vegetation response to three levels of fire severity (low (LS), moderate (MS) and high (HS) severity), also including an adjacent unburned forest (UN), which were assessed one, two and three years after fire. We also evaluated the impact of cattle on plant recovery after fire. We measured species richness, abundance, plant diversity and origin of all vascular plant species.

Results: Species richness and plant abundance responded differently to fire severity. Time-since-fire had a significant effect on plant richness and abundance. Plant composition within $L S$ areas was similar to UN areas, but MS and HS areas were significantly less diverse compared to UN and LS. In absence of other major disturbances, similarity in plant composition tended to increase over time across the different levels of fire severity, becoming more similar to UN. We also found a synergetic effect of cattle and fire on species richness. This interaction promotes the establishment of nonnative species and limits the recovery of native species following fire.

Conclusions: Fire severity had a significant impact on the plant community of old-growth Araucaria-Nothofagus forests, especially in areas of high fire severity, where the native tree N. pumilio was completely absent. Nevertheless, plant communities can recover gradually, depending on fire severity, time-since-fire, and the absence of cattle grazing. Management actions should include the exclusion of cattle within fire-affected areas and afforestation with N. pumilio in areas high fire severity due to its unsuccessful recruitment after fire.
\end{abstract}

Keywords: Fire severity gradient, Wildfire, Post-fire plant recovery, Cattle exclusion, Synergistic effects of disturbances, Araucaria araucana, Nothofagus pumilio

\footnotetext{
* Correspondence: andres.fuentes@ufrontera.cl

'Laboratorio de Biometría, Departamento de Ciencias Forestales, Universidad

de La Frontera, Casilla 54-D, Temuco, Chile

${ }^{3}$ Butamallin Research Center for Global Change, Universidad de La Frontera,

Temuco, Chile

Full list of author information is available at the end of the article
} 


\section{Background}

Biotic and abiotic disturbances are the main drivers, after climates, shaping the structure and composition of forest ecosystems worldwide (Ross et al. 2002; Seidl et al. 2017). Disturbance regimes can be modified by climate change, but they could be also amplified (i.e., increasing their frequency and severity) by human activities (Bowman et al. 2009; Mundo et al. 2013). Fire has been present on Earth since the very beginning of the appearance of terrestrial plants (Bowman et al. 2009), and today, fire is understood as an important disturbance in many ecosystems around the globe.

Fire can alter vegetation structure (e.g., emergent, dominant and under-canopy vegetation), soil properties (e.g., nutrients and microbial communities), and other ecosystem functions like productivity and the provision of goods and services (Whelan 1995; Sugihara et al. 2006). To date, a great deal of the literature has focused on explaining how fire regimes are changing around the globe due to climate change (Grissino-Mayer and Swetnam 2000; Bowman et al. 2009) and to historical fire suppression ( $\mathrm{Li}$ et al. 2005). When the natural fire regime changes in frequency, severity and seasonality, it can constrain the resilience of natural ecosystems, making the forest more prone to fire, and ultimately threatening the more firesensitive species. Thus, forest ecosystems affected by repeated high-severity fires might require restoration actions to prevent further degradation (Reyer et al. 2015). On the other hand, when fire occurrence is relatively frequent, and is associated to the dynamic of the forest itself, there can be patchy patterns in the vegetation, with fire-tolerant species displaying adaptations (e.g., thick bark to protect the living tissues; Burns 1993; Keeley 2012), post-fire vigorous germination and resprouting, and rapid colonization after fire by fire-adapted non-native species (Bond and van Wilgen 1996).

Temperate forests in south-central Chile that are dominated by the native conifer Araucaria araucana (Mol.) K. Koch are associated to natural fire regimes. For $A$. araucana and Nothofagus pumilio (Poepp. \& Endl.) Krasser (hereafter termed as Araucaria-Nothofagus forests), dendrochronology studies have allowed to reconstruct part of the fire history in the region (by using tree ring analyses), showing a mixed-severity fire regime impacting these forests in the last 400 years (González et al. 2005; González and Veblen 2007; González et al. 2018). Araucaria araucana allows the study of the historical fire regime because it is a long-lived conifer that is adapted to low-to-moderate fire severities due to its thick bark (Burns 1993), in which fire scars are used to date fire events. However, for N. pumilio, a thin-barked, broad-leafed deciduous tree that is commonly found in association with $A$. araucana, the risk of being killed by a severe fire is much higher than for A. araucana as this species is an obligated seeder that cannot resprout after fire (González et al. 2005; Mundo et al. 2013). Fire is an important factor that shapes the structure and composition of Araucaria-Nothofagus forests in the southern Andes, and it has been evident that the occurrence and severity of wildfires have significantly increased in southcentral Chile (Úbeda and Sarricolea 2016; McWethy et al. 2018). Example of this was the fire season of 20142015, which represents the worst period for AraucariaNothofagus forests in the last 50 years (González and Lara 2015).

Old-growth forests formed by A. araucana are particularly valuable because of their significant biodiversity and cultural values (Aagesen 1998; dos Reis et al. 2014). By year 1500, prior to the Spanish colonization, $A$. araucana forests covered ca. 500,000 ha in Chile. This area was reduced by almost $50 \%$ due to logging and fires during the 1920-1970s Euro-Chilean colonization (Lara et al. 1999). In addition, indigenous Pehuenche communities have used fire to clear the forest to open passes over the mountains, to facilitate hunting, and for habilitating lands for agriculture and cattle rising (Veblen et al. 2003; González et al. 2005; Mundo et al. 2013). Currently, A. araucana is classified as an endangered species in Chile and it was declared Natural Monument in 1990, with complete prohibition of logging. Araucaria araucana populations outside national parks and reserves are still experiencing an increased risk of degradation, being subjected to logging (González and Veblen 2007), cattle grazing (Fuentes-Ramirez et al. 2011; Zamorano-Elgueta et al. 2012), increasing and unsustainable harvesting of its edible seeds and fire-induced disturbances (Fuentes-Ramirez et al. 2018). Other risks for A. araucana forests include the invasion of exotic plant species (Cóbar-Carranza et al. 2014), the presence of exotic livestock, such as wild boar that forages primarily on its seeds (Sanguinetti and Kitzberger 2010), and browsing and grazing by cattle during the November-May period, which is a traditional practice of Pehuenches. As a result, synergistic effects between fire, invasive species and cattle activity may arise, further affecting the conservation of this unique forests. Nonetheless, the interaction of fire, cattle grazing and the establishment of exotic invasive species have not been deeply examined in Andean Araucaria-Nothofagus forests.

Following severe wildfires, increased solar radiation (due to reduction of forest canopy) and cattle activity, can act as drivers for the invasion of non-native species, which might lead to permanent changes in vegetation composition (Veblen et al. 1992; Pauchard and Alaback 2004). More interestingly, some native species can also affect vegetation composition after fire. Such is the case of Chusquea culeou E. Desv., a woody bamboo with fast recovery after fire that can impede the regeneration of the rest of the vegetation (Blackhall et al. 2008; González et al. 2010). 
Despite the fact that fire is a natural disturbance that has shaped the landscape where Araucaria-Nothofagus forest occurs, there is still little knowledge regarding the impact of severe fires on the rest of the vegetation (including the non-dominant trees and the understory), and the potential impact of cattle in the establishment of non-native plant species following fire (González et al. 2005; Veblen et al. 2008; González and Lara 2015). Given the increasing interest in restoring the Araucaria-Nothofagus forests affected by fires (i.e., with better designs and implementation of restoration practices), it is important to understand the natural dynamics of plant communities after fires of different severities and how that would interplay with other disturbances, such as plant invasions and cattle grazing (Aagesen 1998; Chuong et al. 2016).

The main goal of this research was to assess the early plant dynamics in old-growth Araucaria-Nothofagus forests affected by mixed-severity fires in March of 2015. This setting constitutes a unique opportunity for establishing a natural laboratory to study the post-fire dynamic of plant recovery. Therefore, this research will provide crucial, useful information on plant community dynamics for designing and implementing restoration plans for burned Araucaria-Nothofagus forests. Toward that end, our study was designed to test the hypotheses that (i) plant composition from Araucaria-Nothofagus forests initially differs in their recovery as a function of fire severity, yet over time and in absence of further disturbances, vegetation similarity will increase among areas of different levels of fire severity; and (ii) the interaction between fire and post-fire cattle grazing influences plant species composition in Araucaria-Nothofagus forests. To evaluate the above, we set the following specific goals: a) to describe the annual plant recovery the first (2016), the second (2017) and the third (2018) year after fire within burned areas according to a fire-severity gradient ranging from an unburned forest to areas affected by high fire severity; b) to assess plant richness, abundance, recruitment and plant mortality along the fire severity gradient; c) to evaluate the response of the dominant tree species $A$. araucana and $N$. pumilio along the fire severity gradient; and d) to assess the initial impact of cattle activity in the most severely fire-affected areas and its implication for the potential establishment of invasive species after fire.

\section{Materials and methods}

\section{Study area}

This research was carried out in old-growth AraucariaNothofagus forests in the National Reserve China Muerta (La Araucanía region, south-central Chile, $38^{\circ} \mathrm{S}-71^{\circ} \mathrm{W}$; Fig. 1a). The area has a rugged topography and covers an extension of 11,168 ha, with elevations ranging from 759 to $2000 \mathrm{~m}$ a.s.l. The climate is warm and temperate, with two or three months of drought between December and February. The mean annual temperature for summer (December to March) is $19^{\circ} \mathrm{C}$, whereas for winter (June to September) it is $5^{\circ} \mathrm{C}$. Mean annual rainfall is ca. $2500 \mathrm{~mm}$. Precipitation also includes abundant winter snowfall, which provides enough moisture for plants during the following growing season. The mean annual relative humidity is $85 \%$ (Kottek et al. 2006). Soils correspond to Andosols and Histosols that were developed from recent volcanic ashes (Center for Information of Natural Resources - CIREN 2010). These soils are well-stratified, deep and dark brown in color, with coarse texture and permeable throughout the profile. The vegetation belongs to the Andean-Patagonian forests, and to a lesser extent to the Andean deciduous forest (Gajardo 1994). The dominant native tree species are $A$. araucana and $N$. pumilio. The understory vegetation is represented by the shrubs C. culeou, Maytenus disticha (Hook. f.) Urb.

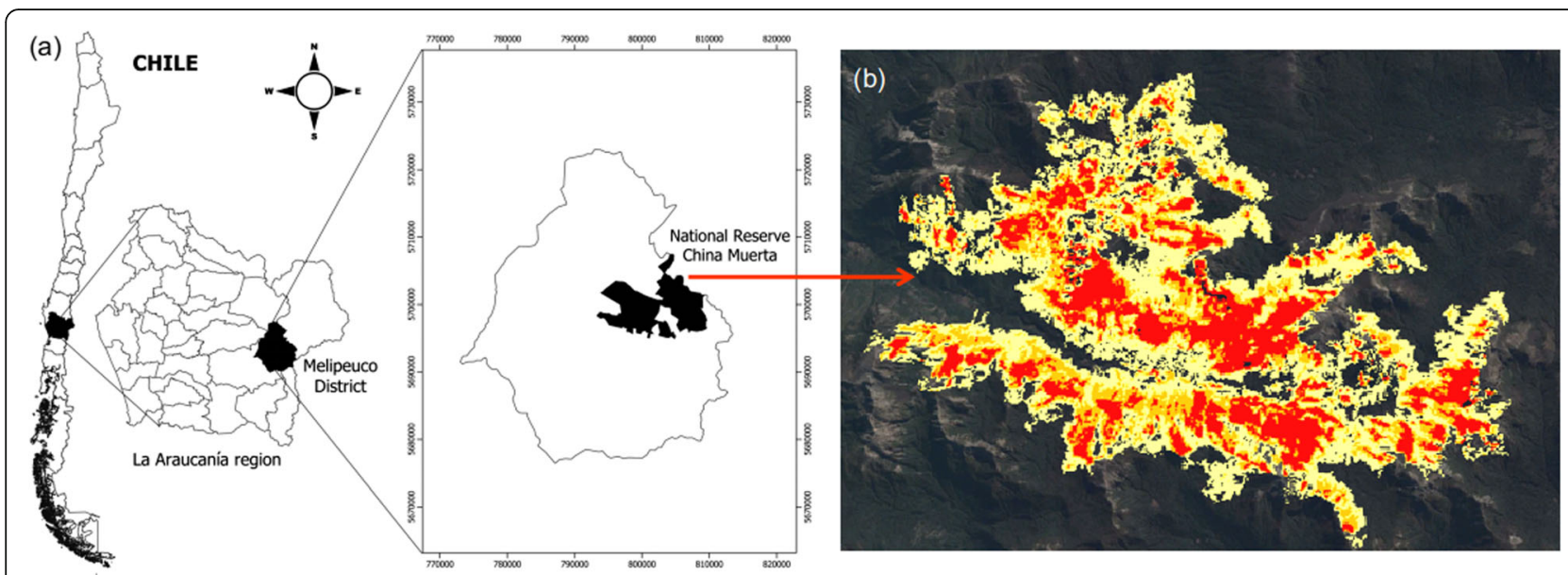

Fig. 1 (a) Geographic location of the study area in the National Reserve China Muerta, Melipeuco District, La Araucanía region (385, $71^{\circ}$ W), southcentral Chile, and (b) the fire model that was developed to define severity levels: low (yellow), moderate (orange) and high (red). Source: Laboratorio de Teledetección Satelital, Departamento de Ciencias Físicas, Universidad de La Frontera 
and Gaultheria poeppiggi DC., and the herbaceous layer by Osmorhiza chilensis Hook. \& Arn., Adenocaulon chilense Less., and Viola magellanica G. Forst. (Urrutia-Estrada et al. 2018). In the study area, $A$. araucana populations can occur in pure stands ( $>90 \%$ canopy cover) or mixed with $N$. pumilio. It is worth mentioning that our study area is part of a National Reserve, where extensive cattle grazing occurs from late spring to late fall (November to May) as a traditional practice of indigenous Pehuenche communities. Although there is no official record of the number of heads that graze in the National Reserve, unofficial estimates approximate to $50-60$ cattle heads per season, which is fairly high for a relatively small area where our study took place (ca. 60 ha).

\section{Description of the forest fire}

In March 15th of 2015, at the end of summer season, a wildfire started apparently by an accidental, unextinguished campfire. The fire was active for 23 days and was brought under control on April 6th. A total of 3765 ha of Araucaria-Nothofagus forests were burned. The fire was facilitated by a preceding megadrought that had affected the south-central region of Chile since 2010 (Garreaud et al. 2017). By using satellite imagery analyses (i.e., Landsat-8/OLI) and the dNBR index (differential normalized burn ratio; Key and Benson 1999), the Chilean Forest Service (CONAF) defined three levels of fire severity: high, moderate and low. The areas of high severity (HS) presented a dNBR index $>0.6$; areas of moderate severity (MS) had a dNBR between $0.60-0.35$, and areas of low severity (LS) between 0.35-0.10 (Mora and Crisóstomo 2016). Subsequently to the classification developed by CONAF, there were characterizations in the field, and each level of severity was defined as follows: areas of HS suffered crown fires and had trees completely burned, as well as the understory that was totally charred. In MS areas, trees were partially burned, the forest canopy presented some unburned branches, and there was still understory vegetation in the lower layers. Finally, areas of LS had a superficial fire, with slight damage caused by the fire and most of the trees and understory vegetation being unburned. In addition, soil nutrients within the burn gradient have showed an overall decrease after fire, especially in areas of high fire severity (Fuentes-Ramirez et al. 2018; Muñoz-Gomez, in prep.). The extension of each fire-affected area was approximately 970 ha in HS, 910 ha in MS and 1890 ha in LS (Mora and Crisóstomo 2016; Fig. 1b). In addition, we used an adjacent unburned Araucaria-Nothofagus forest (UN) to serve as reference ecosystem. The UN forest presented a dNBR index $<0.1$, and is considered an old-growth forest, with an uneven-aged distribution, a total basal area of $100 \mathrm{~m}^{2} \cdot \mathrm{ha}^{-1}$ dominated by $N$. pumilio (60\%), and A. araucana (40\%), and an average height of the upper-crown classes of ca. $32 \mathrm{~m}$.

\section{Design and data collection}

Within the burned zone we selected an experimental area of $1200 \mathrm{~m}$ long including the three fire severity levels and the unburned forest, which presented homogeneous site conditions: mean elevation $1425 \mathrm{~m}$ a.s.l., aspect N-NE, slope $10 \%-20 \%$, and similar neighboring vegetation. In this experimental area, we randomly established a total of 20 permanent square sample plots of $100 \mathrm{~m}^{2}$ (i.e., five per each severity level including the UN condition; see Additional file 1). Within each plot, we sampled all vascular plants in the summer season (January) of 2016, 2017 and 2018, which corresponds to one, two and three years after fire, respectively. The unburned plots (UN) were only measured in 2016 (i.e., one year after fire), as the area did not experience further disturbances, and weather conditions were similar in the following years (2017 and 2018).

In addition, during the summer of 2017 we established an extra set of permanent plots within the most fireaffected areas (in HS and MS conditions), and along the same experimental area to know the initial impact of cattle activity on vegetation recovery and its potential interaction with fire. The setting of the exclusion plots was specifically designed to avoid the entrance of cows into the most fire-affected areas. Cattle is the major disturbance agent in the study area due to the historical (and current) use by Pehuenche communities. We chose to establish the exclusion plots in HS and MS only because we observed in the field that cows were more frequently seen within these two areas. We also evidenced increased signs of cattle activity in these areas i.e., high number of dungs and high number of plants with damage caused by cattle (e.g., browsing). Two 10 $\mathrm{m} \times 10 \mathrm{~m}$ exclusion plots were set within MS areas (labeled as EX-MS) and two within HS areas (labeled as EX-HS). These plots were enclosed with a five-thread wire fence fixed in the ground with wooden poles, avoiding the entrance of cattle. Once established, these plots were assessed in next growing season (summer of 2018). Thus, our entire sampling design encompassed a total of $24,100 \mathrm{~m}^{2}$ plots (i.e., $N=20$ plots without exclusion +4 exclusion plots $=24$ plots of $10 \times 10 \mathrm{~m}$ each).

Within all the permanent plots (i.e., with and without exclusion) we measured a suit of ecological variables, including species richness, plant abundance (i.e., the number of individuals at the plot scale), life form (i.e., trees, shrubs and herbs) and species origin (i.e., native or non-native species). We recorded all plant individuals with height $\geq 5 \mathrm{~cm}$. This decision was made based on the difficulty to correctly identify seedlings at the very early stage of establishment. If shoots from the same species 
were $<5 \mathrm{~cm}$ apart from each other, we recorded them as a single individual. Each sampled individual was marked with a metallic tag that allowed its re-measurement every year. Plant taxonomy and species identification followed Matthei (1995) for grasses and forbs and Teillier et al. (2014) for shrubs and trees.

\section{Data analysis}

For analyzing the response of plant species richness, we calculated the accumulated species richness for each year (2016, 2017 and 2018) and compared it between levels of fire severity (including the UN condition and the exclusion plots). We performed for each year randomization tests, with 999 randomizations and $\alpha=$ 0.05 to test the difference in the species richness between the fire severity levels. We used the $\mathrm{R}$ package "rich" (Rossi 2011) for computing this test. We also computed the Shannon-Wiener diversity $\left(H^{\prime}\right)$ and Pielou's evenness $\left(J^{\prime}\right)$ indexes for each severity level (including the UN condition and exclusion plots) using the "vegan" package in R (Oksanen et al. 2018), and performed a paired $t$ test to identify statistical difference among the different fire severity levels.

To know the response of plant abundance to fire severity and time since fire, we conducted a Generalized Linear Mixed Model analysis (GLMM). We used plots as random factor, and time since fire (years) and fire severity level as fixed terms. Post-hoc Tukey tests (with $\alpha=0.05$ ) were carried out to compare the mean abundance among fire severity levels and across years. Similar analyses were performed for the cattle-excluded plots within the HS and MS conditions. These analyses were performed using the "lme4" and "emmeans" R packages (Bates et al. 2015; Lenth 2019).

Finally, a non-metric multidimensional scaling (NMDS) ordination analysis was used to evaluate the potential change in the trajectory of vegetation composition along the fire severity gradient over time (Clarke 1993). This analysis was carried out using the "vegan" package, with the Sørensen distance measure and the number of dimensions $k=2$. To complement the previous analysis, we performed an Indicator Species Analysis (ISA), which provides further evidence of the impacts of fire on plant composition and its dynamics over time by the identification of the species that are more strongly associated to a given fire severity level (or to several levels), combining the proportional abundance and proportional frequency of a given species (McCune and Grace 2002). For this, we conducted a Multi-level Pattern Analysis (multipatt function) using the "indicspecies" $\mathrm{R}$ package (De Caceres and Legendre 2009), and ran 999 permutations with $\alpha=0.05$. All the above-mentioned analyses were performed using the statistical software R (R Core Team 2019).

\section{Results}

Post-fire dynamics of vegetation Species richness

In the unburned forest (UN), which we assume corresponds to the condition prior to fire, we recorded 31 vascular plant species. Only one species was non-native within UN (i.e., Cerastium arvense L.). When considering the species recovering within the burned areas (i.e., LS, MS and HS), in 2016 the pooled richness was 43 species (with $16.3 \%$ of non-native). In 2017, we recorded a total of 49 species, with $20.4 \%$ of non-natives species. In the third year (2018) we recorded a pooled richness of 55 species, with $18.2 \%$ of non-natives. The common species that were found across the entire fire severity gradient, and for the three years of the study were $A$. araucana, Alstroemeria aurea Graham, Berberis microphylla G. Forst., C. culeou, G. poeppiggi and Vicia nigricans Hook. \& Arn. (see Additional file 2). Along the fire gradient, we registered 14, 15 and 34 species for HS, MS and LS one year after fire (2016), respectively (Fig. 2). The increment in species richness was $71.4 \%$ in HS, 93.3\% in MS and only $14.7 \%$ in LS in the third year after fire (Fig. 2, Table 1). In terms of non-native plants, we recorded six species that were absent in the UN, but frequent in LS one year after fire: Cirsium arvense (L.) Scop., Holcus lanatus L., Hypochaeris radicata L., Lactuca serriola L., Rumex acetosella L. and Veronica serpyllifolia L. Two years after fire, two new non-native species appeared

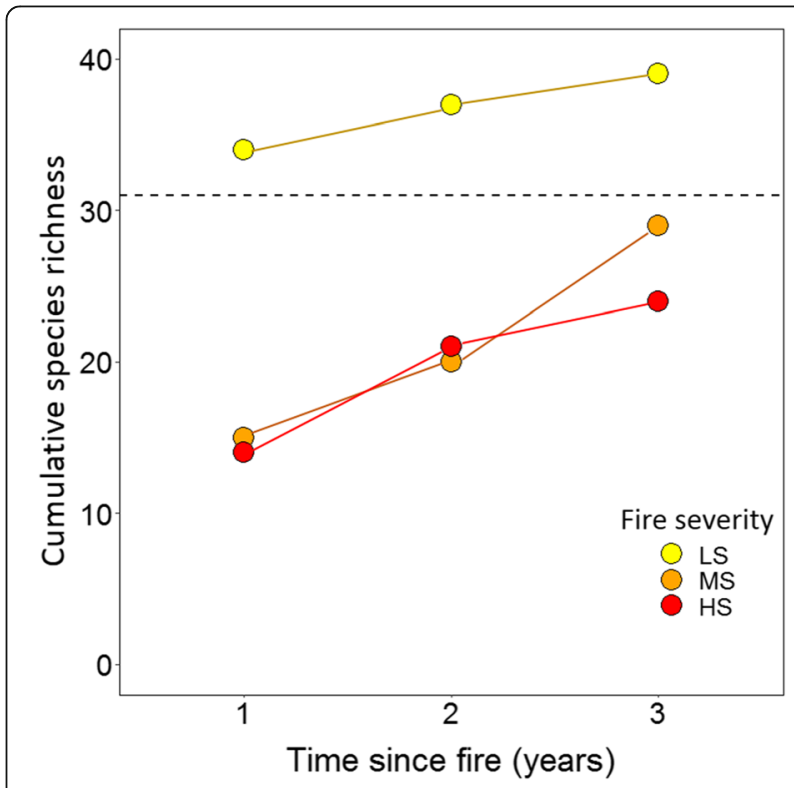

Fig. 2 Cumulative plant richness over time for areas of high fire severity (HS), moderate severity (MS) and low fire severity (LS) in oldgrowth Araucaria-Nothofagus forests affected by a mixed-severity fire in March 2015. Note that species richness in the unburned forest $(\mathrm{UN})$ is 31 , and it is represented by the horizontal dashed line in the plot 
Table 1 Species richness and mean values of Shannon-Wiener diversity index $\left(H^{\prime}\right)$ and Pielou's evenness index $\left(J^{\prime}\right)$ for each fire severity level and for each year of study

\begin{tabular}{|c|c|c|c|c|c|c|}
\hline \multirow[t]{2}{*}{ Year } & \multirow{2}{*}{$\begin{array}{l}\text { Fire } \\
\text { severity } \\
\text { level }\end{array}$} & \multirow[t]{2}{*}{ Richness } & \multicolumn{2}{|c|}{ Richness comparison } & \multirow{2}{*}{$\begin{array}{l}\text { Mean } \\
\text { diversity } \\
\text { index } H^{\prime}\end{array}$} & \multirow{2}{*}{$\begin{array}{l}\text { Mean } \\
\text { evenness } \\
\text { index } J^{\prime}\end{array}$} \\
\hline & & & $\pm U N$ & $p$-value & & \\
\hline \multirow[t]{3}{*}{2016} & LS & $34 \mathrm{a}$ & +3 & 0.377 & $2.13 \mathrm{a}$ & $0.75 a$ \\
\hline & MS & $15 \mathrm{~b}$ & -16 & $0.006^{* *}$ & $0.98 b^{*}$ & $0.51 \mathrm{a}$ \\
\hline & $\mathrm{HS}$ & $14_{b}$ & -17 & $0.004^{* *}$ & $1.16_{b}$ & $0.66 \mathrm{a}$ \\
\hline \multirow[t]{3}{*}{2017} & LS & $37 a$ & +6 & 0.232 & $2.11 \mathrm{a}$ & $0.70 \mathrm{a}$ \\
\hline & MS & $20 b$ & -11 & $0.007^{* *}$ & $1.15_{b}^{*}$ & $0.53 b$ \\
\hline & $\mathrm{HS}$ & $21 \mathrm{~b}$ & -10 & $0.041^{*}$ & $1.32 \mathrm{~b}$ & $0.65 \mathrm{ab}$ \\
\hline \multirow[t]{3}{*}{2018} & LS & 39 a & +8 & 0.188 & $2.08 \mathrm{a}$ & $0.68 \mathrm{a}$ \\
\hline & MS & $29 \mathrm{ab}$ & -2 & 0.340 & $1.35 \mathrm{~b}$ & $0.52 b$ \\
\hline & $\mathrm{HS}$ & $24 b$ & -7 & $0.050^{*}$ & $1.44 \mathrm{~b}$ & $0.61 \mathrm{ab}$ \\
\hline
\end{tabular}

Species richness within the UN is 31 , mean $H^{\prime}$ is 1.77 and mean $J^{\prime}$ is 0.63 . Different letters represent statistically significant differences (at $a=0.05$ ) between the periods of evaluation within each year, and the significant differences between LS, MS and HS compared to the UN are represented by ** for $p<0.01$ and ${ }^{*}$ for $p<0.05$

in LS: Cirsium vulgare (Savi) Ten. and Trifolium repens L., and in the third year, only one new non-native was added to LS areas: Poa sp. (see more details in Additional file 2).

Species richness from HS and MS areas was significantly lower than the richness in UN during the three years after fire (all $p$-values $<0.05$; Table 1 ). However, the difference in species richness among these conditions tended to decrease over time (Table 1). When examining richness within a same fire severity level, the plant community presents a slight increase in the
Shannon's diversity index $\left(H^{\prime}\right)$ over time (from 0.98 to 1.35 and from 1.16 to 1.44 one and three years after fire in MS and HS, respectively). Low severity (LS) areas showed a slight decrease in diversity over time (from 2.13 to 2.08 , one and three years after fire). Pielou's evenness index, though, showed virtually no changes over time nor across the fire severity gradient.

\section{Plant composition}

The NMDS ordination diagram showed that plant community composition (for all plots across the fire severity gradient) was clustered into two main groups: one for the plots from UN and LS, and another group for HS and MS plots. The former presented shorter distance between plots, whereas the latter showed that the plots were more spread-out in the ordination diagram (Fig. 3a). Nevertheless, in the third year of evaluation (2018), plant composition from all the fire-affected plots tended to converge closer to the unburned forest (UN). Interestingly, the most severely affected areas (i.e., HS and MS) revealed greater trajectories towards the UN forest over time (Fig. 3a). The variables that better explain the trajectories were richness, plant abundance and fire severity (all $p$-values < 0.001) (Fig. 3b).

Indicator species analysis showed that statistical differences were significant only for $30 \%$ of the species in the three years of the study, which means that they play an important role as indicator species for a given severity level. From those species, only eight had complete specificity to a given fire severity level or to a combination of them. These species include Lagenophora hariotii Franch.

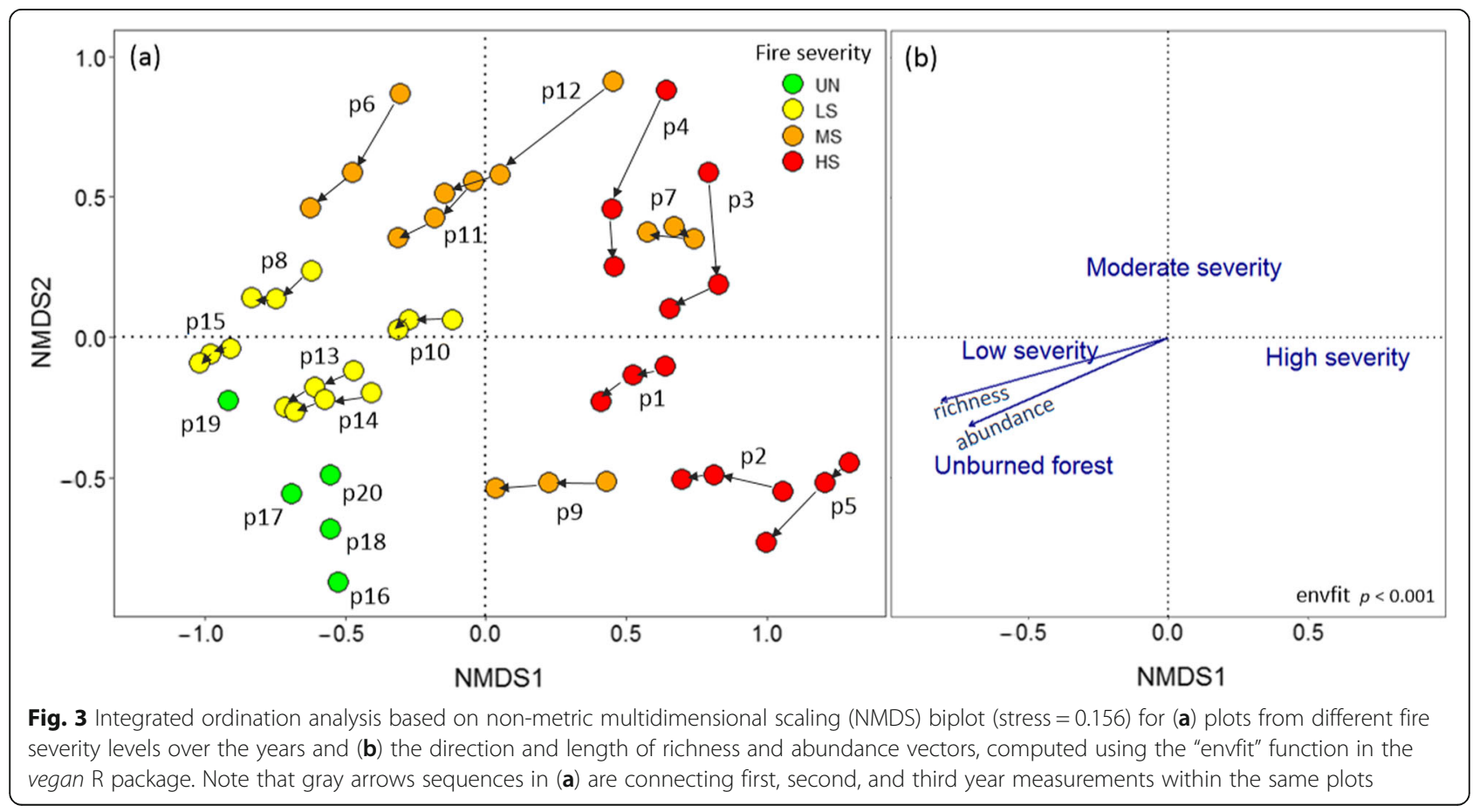


for UN and Osmorhiza chilensis for UN and LS, among others (Table 2).

\section{Plant abundance}

Mean plant abundance in the UN forest was $47,640 \pm$ 3943 (mean \pm SE) plants.ha ${ }^{-1}$. Within each year of evaluation, there were statistically significant differences in plant abundance between each fire severity level (Fig. 4a). In addition, HS and MS were statistically different from UN over time, excepting MS in the last year of evaluation (Fig. 4a). Plant abundance in LS areas showed no difference from the UN over time (Fig. 4a). Within the same fire severity condition, but looking at each year of evaluation, mean plant abundance was statistically different from the first to the second, and the third year of evaluation (Fig. 4b). We also found a significant interaction

Table $\mathbf{2}$ List of indicator species that are strongly associated to each fire severity level and to the unburned forest (using 999 random permutations at $a=0.05$ )

\begin{tabular}{|c|c|c|c|}
\hline Group/species & A & B & $p$-value \\
\hline \multicolumn{4}{|l|}{ Unburned forest (UN) } \\
\hline Myoschilos oblongum & 0.99 & 1.00 & $0.001^{* * *}$ \\
\hline Gavilea lutea & 0.80 & 0.80 & $0.015^{* *}$ \\
\hline Lagenophora hariotii & 1.00 & 0.60 & $0.027^{*}$ \\
\hline Perezia prenanthoides & 1.00 & 0.60 & $0.027^{*}$ \\
\hline \multicolumn{4}{|l|}{ Low severity (LS) } \\
\hline Acaena ovalifolia & 0.94 & 1.00 & $0.001^{* * *}$ \\
\hline Berberis serratodentata & 0.93 & 1.00 & $0.002^{* *}$ \\
\hline Ribes trilobum & 0.89 & 1.00 & $0.001^{* * *}$ \\
\hline Uncinia scabriuscula & 0.87 & 1.00 & $0.001^{* * *}$ \\
\hline Veronica serpyllifolia & 0.77 & 0.80 & $0.035^{*}$ \\
\hline \multicolumn{4}{|l|}{ High severity (HS) } \\
\hline Eleocharis melanostachys & 1.00 & 0.80 & $0.008^{* *}$ \\
\hline Epilobium glaucum & 0.81 & 0.80 & $0.020^{*}$ \\
\hline \multicolumn{4}{|l|}{$U N+L S$} \\
\hline Maytenus disticha & 0.97 & 1.00 & $0.001^{* * *}$ \\
\hline Nothofagus pumilio & 0.96 & 1.00 & $0.001^{* * *}$ \\
\hline Osmorhiza chilensis & 1.00 & 0.90 & $0.001^{* * *}$ \\
\hline Adenocaulon chilense & 1.00 & 0.80 & $0.003^{* *}$ \\
\hline \multicolumn{4}{|l|}{ UN + Moderate severity (MS) } \\
\hline Senecio pilquensis & 1.00 & 0.80 & $0.003^{* *}$ \\
\hline \multicolumn{4}{|l|}{$L S+M S$} \\
\hline Alstroemeria aurea & 0.96 & 0.90 & $0.016^{*}$ \\
\hline Montyopsis gayana & 1.00 & 0.70 & $0.017^{*}$ \\
\hline \multicolumn{4}{|l|}{$U N+L S+M S$} \\
\hline Ribes magellanicum & 1.00 & 0.93 & $0.003^{* * *}$ \\
\hline
\end{tabular}

between fire severity and time-since-fire on plant abundance $(p<0.01)$.

The most abundant species within the UN forest were M. disticha and G. poeppigii, with 16,540 ind. $\mathrm{ha}^{-1}$ (35\% of total abundance) and 11,980 ind. ha $^{-1}$ (25\% of total abundance), respectively (Fig. 5a). Meanwhile, in LS the most abundant species were $M$. disticha, $N$. pumilio, Berberis serratodentata Lechl. and A. aurea, encompassing $>60 \%$ of the total abundance in each year of evalu-

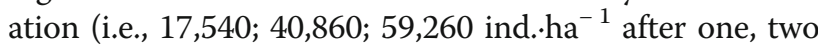
and three years since fire, respectively; Fig. 5b). For MS, the contribution of A. aurea, C. culeou and G. poeppigii accounted for $>75 \%$ of the total abundance in the first year (8420 ind.ha $\left.{ }^{-1}\right)$, the second (14,720 ind. $\left.\mathrm{ha}^{-1}\right)$ and third (22,500 ind.ha ${ }^{-1}$ ) year of evaluation (Fig. 5c). Finally, the shrubs C. culeou and G. poeppiggi, and the forb $A$. aurea were the most abundant species within HS during all years of evaluation, with $>71 \%$ of presence in the total abundance in the first year (3100 ind. $\mathrm{ha}^{-1}$ ), $63 \%$ in the second (5020 ind.ha ${ }^{-1}$ ) and $67 \%$ in the third year (8940 ind. ha $^{-1}$ ) after fire (Fig. 5d). Regarding the increment in plant abundance over time (i.e., establishment new individuals with respect to the previous year), we found that the species with the highest recruitment in LS were A. aurea, $M$. disticha and B. serratodentata. In MS, $A$. aurea was the species with the highest recruitment in both years (53\% in 2017 and 47\% in 2018), and within HS, G. poeppigii had a $40 \%$ increase in recruitment in 2017 and 56\% in 2018. It is worth mentioning that plant mortality along the fire severity gradient, and during the three years of evaluation was very low, with $<9 \%$ and $<6 \%$ of the total abundance registered in 2017 and 2018, respectively. The species with the overall greatest mortality in the three years of evaluation were the forb A. aurea, and the shrubs G. poeppigii and C. culeou.

Fire impact on Araucaria araucana and Nothofagus pumilio We also found that fire greatly affected the dominant native trees $A$. araucana and $N$. pumilio. Within the unburned forest (UN), $N$. pumilio was the third most abundant species with 3680 ind. ha ${ }^{-1}$, and $A$. araucana was the sixth, with 2120 ind.ha ${ }^{-1}$, which represents $8 \%$ and $5 \%$, of the total abundance registered in the unburned forest, respectively. Nonetheless, N. pumilio was completely absent in HS areas in the first (2016), the second (2017) and even in the third (2018) year after fire (Table 3).

In the understory of LS, we found that most of the individuals from both species were alive one year following fire (2016), with only slight signals of fire damage. Two years after fire, we registered a recruitment of $125 \%$ and $53 \%$ for A. araucana and N. pumilio regarding the previous year, respectively (Table 3). For 


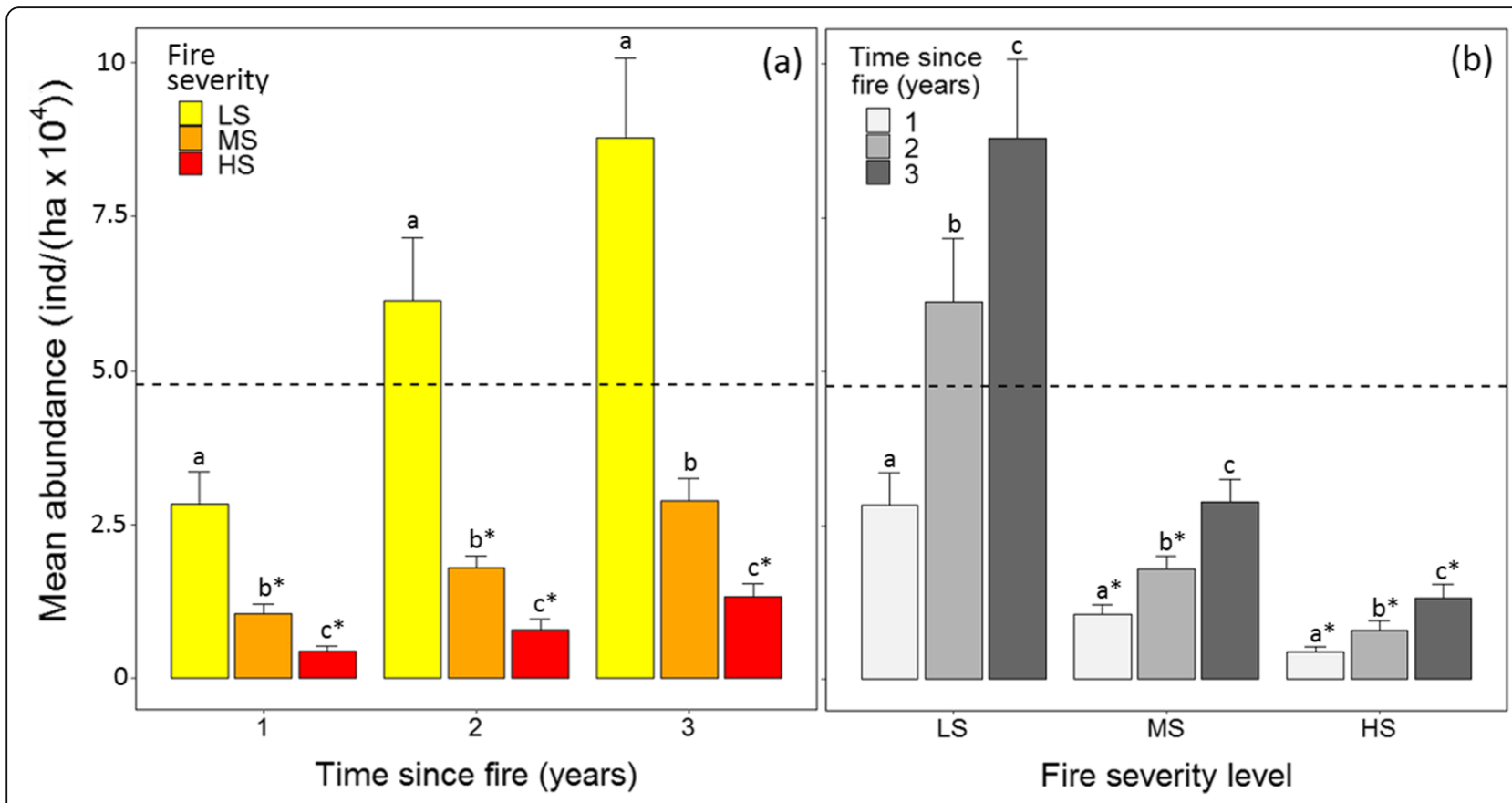

Fig. 4 Mean plant abundance (+SE) in burned Araucaria-Nothofagus forests for (a) each year of evaluation, and (b) each fire severity level. Note that lowercase letters indicate statistically significant differences (using Tukey's test at $a=0.05$ ) between the bars for a given year or fire severity level, and the * indicates significant differences (using Tukey's test at $a=0.05$ ) between the bars and the unburned forest (UN), which is represented by a dashed line with a mean abundance of 47,640 ind. ha ${ }^{-1}$

areas of MS, we found individuals of A. araucana with half green branches, and individuals of $N$. pumilio with new resprouting buds, with a density of 160 and 360 plants.ha ${ }^{-1}$, respectively (Table 3 ). We did not find new individuals from both species after two years of the fire (2017), but in the third year the increase in abundance was $137.5 \%$ for A. araucana and $27.7 \%$ for
N. pumilio. In HS we found individuals of A araucana that resprouted from the stem base or emerging from seeds, with just 120 plants.ha ${ }^{-1}$ after one year following the fire. Then in the second year, the abundance of $A$. araucana doubled compared to the previous year, but we did not find any recruitment of this species during the third year.

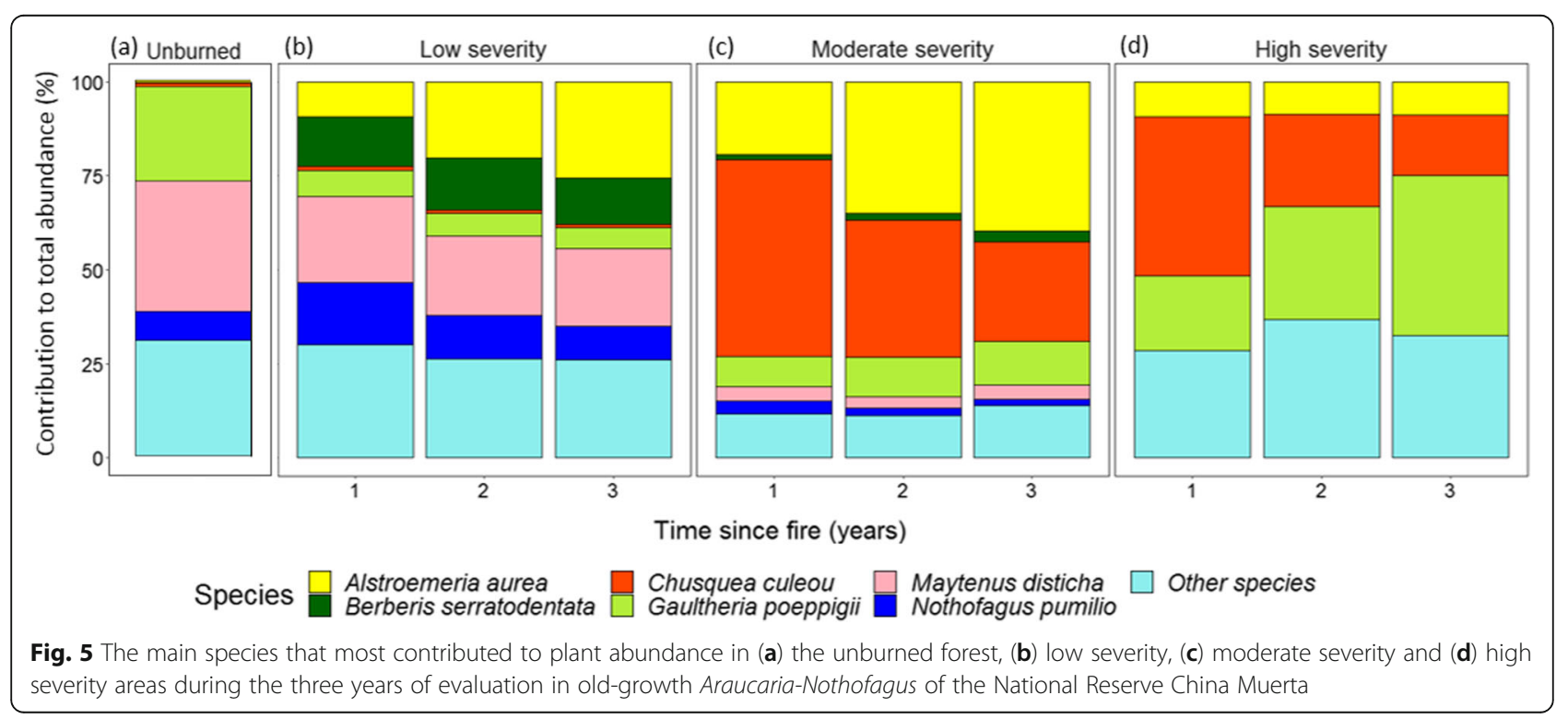


Table 3 Density of Araucaria araucana and Nothofagus pumilio along the fire severity gradient for each year of study

\begin{tabular}{|c|c|c|c|c|c|c|}
\hline \multirow[t]{2}{*}{ Year } & \multicolumn{3}{|c|}{$\begin{array}{l}\text { Araucaria araucana } \\
\left.\text { Mean abund. (ind. } h a^{-1}\right) \pm S E\end{array}$} & \multicolumn{3}{|c|}{$\begin{array}{l}\text { Nothofagus pumilio } \\
\left.\text { Mean abund. (ind. } \mathrm{ha}^{-1}\right) \pm \mathrm{SE}\end{array}$} \\
\hline & $\overline{\mathrm{LS}}$ & MS & $\mathrm{HS}$ & $\overline{L S}$ & MS & $\mathrm{HS}$ \\
\hline 016 & $160 \pm 40$ & $160 \pm 68$ & $120 \pm 97$ & $4680 \pm 2207$ & $360 \pm 360$ & 0 \\
\hline 017 & $360 \pm 186$ & $160 \pm 68$ & $240 \pm 144$ & $7160 \pm 3344$ & $360 \pm 360$ & 0 \\
\hline 018 & $580 \pm 318$ & $380 \pm 174$ & $240 \pm 150$ & $8000 \pm 3734$ & $460 \pm 460$ & 0 \\
\hline
\end{tabular}

Note that the abundance of $A$. araucana and N. pumilio in the unburned forest (UN) was 2120 and 3680 ind.ha ${ }^{-1}$, respectively

\section{Impact of cattle on plant recovery}

We registered a total pooled richness of 33 species in the plots that were excluded from cattle in MS and HS levels. Five species were found exclusively in these plots (i.e., they only appeared when the cattle was excluded): Aira caryophyllea L. (non-native), Crepis capillaris (L.) Wallr. (non-native), Galium fuegianum Hook. F. (native), Epilobium densiflorum Hausskn. (native) and Carduus thoermeri Wainm. (non-native) (see Additional file 2). A total of 18 species were found in the EX-MS plots and 28 species in EX-HS (from which $22.2 \%$ and $21.4 \%$ were non-natives, respectively). Interestingly, neither of the exclusion plots showed a significant difference in their species richness compared to the unburned forest (randomization tests, all $p$-values $>0.05$ ). Within the same fire severity level, we found that plant richness was significantly higher in EX-HS compared to HS in the third year of evaluation (2018), but EX-MS did not differ in plant richness compared to MS level in 2018.

Mean plant abundance within the EX-MS plots was $62,750 \pm 46,750$ (mean \pm SE) ind. ha $^{-1}$, and 14,700 \pm 3000 (mean \pm SE) ind. ha $^{-1}$ in EX-HS, which neither of them was statistically different from the plots without exclusions in MS and HS areas in the third year of evaluation (2018). The most abundant species within the exclusion plots were G. poeppigii (48\% of the total abundance) and B. microphylla (25\%) in EX-MS, which were greater than in the non-excluded MS areas. For EX-HS, G. poeppigii and C. culeou had the greatest abundance (with 37\% and $25 \%$, respectively), which was very similar to the nonexcluded plots in the HS areas in 2018. For non-natives, Agrostis capillaris L. was the most abundant species inside the exclusion plots. Finally, for the dominant tree species, we found seven individuals of $A$. araucana within EX-MS and none in EX-HS. Nothofagus pumilio was not found in neither of the exclusion plots.

\section{Discussion}

\section{Plant richness and species composition after fire}

The fire that burned the National Reserve China Muerta in 2015 significantly affected the understory plant composition and the recovery of dominant tree species $A$. araucana and $N$. pumilio, especially one year after fire.
Interestingly, our study revealed that areas of low fire severity (LS) presented increased species richness, which was even higher than in the unburned areas (UN) for the three years of evaluation. These results support the intermediate disturbance hypothesis (Connel 1978), and have also been observed in other ecosystems worldwide. Blair et al. (2016) reported that unburned forests have fewer species than areas burned with low fire severity in the mountain ash forests of the Victorian Central Highlands (Australia). Similarly, Reilly et al. (2006) found that species richness also increased at different spatial scales after fire in the southern Appalachian forests (USA). In this sense, fire can act as a "breaker of inertia", prompting the release of soil nutrients, and promote species that were previously absent in the site, but readily available in the seed bank (Ross et al. 2002; Reilly et al. 2006). Our study showed that the increase of plant diversity in the burned areas is marked by the presence of non-native species, which are quite common in disturbed areas of south-central Chilean forests (Pauchard and Alaback 2004). Hence, fire can alter the site variables and the biochemical characteristic of soil following fire (i.e., microbial activity, nutrient balance and light availability; Fuentes-Ramirez et al. 2018), which in turn might promote the establishment of non-native species, leading to an increased richness shortly after fire (as we found in LS areas). Nevertheless, the presence of nonnative species might decrease in the mid- to long-term in absence of further disturbance due to the increment of nutrient availability, which promotes the establishment and growth of perennial native species (Pickup et al. 2013). Although still with low abundances, all the non-native species found in our study have been reported as invasive in several areas of south-central Chile (Fuentes et al. 2014).

On the contrary, plant diversity significantly decreased within areas of high fire severity (HS and MS) compared to the adjacent, unburned forest (UN), especially one year after fire. However, in the same area (HS and MS), species richness recovered quickly in the second and third year after fire, but still significantly different from the UN forest. This compositional convergence of vegetation after fire is reflected by the trajectory of the plots shown in the NMDS diagram (Fig. 3). The shift of the plots towards UN can be explained by the increase in floristic similarity, especially for the HS and MS levels, where new species already present in the unburned forest and LS established over time.

This heterogeneous response in the recovery of vegetation after fire is responsible of creating a patchy mosaic in the landscape of Araucaria-Nothofagus forests (Pickett and Thompson 1978; Veblen et al. 2005). Nevertheless, and as our results suggest, the forest structure and community composition might be permanently altered after 
fire (Minor et al. 2017), especially for $N$. pumilio in the most fire affected areas. On the other hand, there are species with high probability of establishment after fire, and these species could serve as bioindicators for a given fire severity level (De Caceres and Legendre 2009). In our study, A. aurea, a native forb, was a species that we found as an indicator for MS and LS during the three years of evaluation. Alstroemeria aurea became the predominant species within MS and LS, highly increasing its abundance each year of evaluation. This species has an enhanced plastic response due to its rhizome structure that provides a rapid and successful reproduction after fire (Burns 1993; González et al. 2010).

Regarding shrub species, $M$. disticha and B. microphylla were the most abundant shrubs in the LS level, most likely because of their high capacity for vegetative growth after fire. González et al. (2010) also reported $M$. disticha as a common resprouter in areas of moderate fire severity in Tolhuaca National Park. However, our results show that $M$. disticha is a widespread species with low density in the MS (<4\% of representation), but with a higher abundance in the LS level. Similarly, for $B$. microphylla, Raffaele and Veblen (1998) also indicated that the species has a high vegetative recovery after fire in Nahuel Huapi National Reserve (Argentina), and acts as facilitator for the establishment of other plant species. In MS areas, the native bamboo C. culeou was the most abundant shrub for all years of evaluation, but in HS condition C. culeou was the most abundant only the first year after fire, being surpassed by G. poeppigii in the second and third year after fire. These results are consistent with findings reported by Veblen et al. (2003) and González and Veblen (2007), who also found an initial fast recovery of $C$. culeou, which was followed by an increase in the abundance of Gaultheria mucronata (L. f.) Hook. \& Arn., another Gaultheria species that resprouts vigorously after fire (Burns 1993; González et al. 2010).

\section{Fire impact on dominant tree species}

As stated earlier, high severity fires had a quite significant impact on A. araucana and N. pumilio, the two dominant tree species in the forest, but they showed different responses to fire in their post-fire regeneration strategy. While A araucana is able to withstand low-tomoderate severity fires due to its thick bark (Burns 1993) and a fire-resistant crown at several meters above ground in mature individuals (González et al. 2010), $N$. pumilio is a thin-barked species that can be easily killed by severe fires (González et al. 2005; Veblen et al. 2008). Furthermore, $A$. araucana has the capacity for vegetative resprouting after fire, from both belowground and aerial foliage buds (Fuentes-Ramirez et al. 2019). Araucaria araucana also has a wide range of light tolerance, especially for young individuals that are able to grow underneath Nothofagus species canopy (i.e., N. antarctica; Fajardo and González 2009; González et al. 2010) and can even replace Nothofagus species in the longterm (i.e., 150 years; Burns 1993). On the contrary, $N$. pumilio is considered a shade-intolerant species, but in young stages it can germinate and grow in the understory (Puntieri et al. 1999).

Superficial fires allow increased light availability in the forest floor (Reilly et al. 2006), where N. pumilio seedlings can be favored. This is what we observed in the LS areas, where the abundance of $N$. pumilio consistently grew in the course of the study. A similar response, although not so marked occurred in MS areas, where we registered an increase of $N$. pumilio individuals only from the second to the third year (2017 to 2018). Quite remarkably, and despite the fact that $N$. pumilio is an early colonizer of harsh environments (Fajardo and González 2009), we did not register a single individual of $N$. pumilio within areas affected by high fire severity (HS) in the three years of study. A similar pattern was reported by González et al. (2010), with no regeneration of N. pumilio after a severe fire in Tolhuaca National Park. The absence of this species within areas of HS could be explained by the lack of seed bank in the soil, which was wiped out by the fire or by limited dispersion of seeds due to the lack of seed-sourcing trees in HS areas. Preliminary results on seed bank and seed dispersion of $N$. pumilio have shown no seed arrival nor germination nor seedling establishment of the species within areas of high fire severity in the three years of evaluation (A. Fuentes-Ramirez, pers. communication). As it has been shown in similar studies (Paritsis et al. 2015), we predict that $N$. pumilio will encounter difficulties to recover itself after high severity wildfires, as it needs both seed-sourcing neighboring trees and a sheltered-canopy to establish. In the long-term, this issue could imply an alteration of the structure and functioning of the entire forest ecosystem (Bekker and Taylor 2010; Stoddard et al. 2018).

\section{Cattle activity after fire}

The presence of cattle within burned areas had an overall negative impact on the species richness and plant abundance, especially in areas of high fire-severity. In a similar study conducted in Nothofagus pumilio-Austrocedrus chilensis (D. Don) Pic. Serm. \& Bizzarri forests (in Nahuel Huapi National Park, Argentina), Blackhall et al. (2008) did not find differences in plant richness nor in plant composition when comparing excluded and non-excluded areas from cattle five years after fire. Although slightly different from our findings, where species richness significantly increased in the exclusion plots of HS areas (compared to the non-excluded HS areas), the results from Blackhall et al. (2008) could be explained by the different 
type of forest and the time elapsed since fire, allowing a longer time for the forest to recover towards its pre-fire conditions.

Interestingly, whereas non-native species richness did not differ in the exclusion plots compared to the nonexcluded plots, species identity did change, with Agrostis capillaris being the most abundant non-native species when cattle was removed from HS and MS areas. Agrostis capillaris is a perennial grass that is able to establish itself quickly after a disturbance by spreading through rhizomes and stolons (Fuentes et al. 2014). Its higher abundance in the exclusion plots could be related to its high palatability for cattle (Rumball et al. 1990). Within the area, cattle activity has been observed since the first year after fire. It is worth mentioning that the spread of non-native species can be favored by cattle, which could act as a dispersal vector through the ingestion of seeds or carrying propagules attached to their fur (Chuong et al. 2016). However, we apply a conservative approach for interpreting the impact of cattle activity on plant recovery after fire. In that sense, a limitation of our study could be the short time of evaluation since the exclusions were established and the low number of replicates.

On the other hand, cattle grazing might have acute impacts on native species. According to Veblen et al. (1992) and De Paz and Raffaele (2012), cattle can greatly affect the diversity of plant communities after fire, mainly due to the selection of palatable species (e.g., $C$. culeou), and prompt higher abundances of the species that are less palatable (e.g., B. microphylla). Despite that our study showed that G. poeppigii was the species with higher abundance inside of both of the exclusion conditions (EX-MS and EX-HS), little literature has focused on the impact of cattle browsing on this species after fire. Raffaele et al. (2011) reported that G. mucronata (a species from the same genus), is less palatable for cattle in burned areas of Argentinean Patagonia. From our results, we observed that the native shrubs species $G$. poeppigii and B. microphylla were greatly favored by the exclusion of cattle after fire, promoting their rapid establishment by vegetative resprouting.

\section{Restoration of burned Araucaria-Nothofagus forests}

As wildfires burn the landscape in a patchy pattern, the recognition of different fire severity levels in the forest is crucial for taking the right actions for management and restoration of fire-affected areas (Reilly et al. 2006). In this regard, the findings of our study provide a valuable baseline that can help to design and implement restoration plans for severely burned Araucaria-Nothofagus forest.

In a recent study, Urrutia-Estrada et al. (2018) proposed management actions aiming at avoiding the spread of non-native species by limiting the access of cattle into HS areas. After three years of evaluation, we concur with the recommendations made by Urrutia-Estrada, highlighting the importance of reducing cattle transit within the most fire-affected areas to decrease its impact on the forest recovery. Studies have shown a strong impact of cattle on $A$. araucana forests, mainly because of the negative effect of browsing and trampling, which limits the recovery of the forest (Zamorano-Elgueta et al. 2012). Furthermore, our research found a significant interaction between fire and cattle activity in areas of high severity, which potentially implies cascading effects and the permanent alteration of the forest structure (Blackhall et al. 2008). In this sense, we strongly recommend afforestation with the native tree $N$. pumilio in HS areas, as fire completely suppressed this species in the three years of evaluation that encompassed this study.

\section{Conclusion}

Our findings revealed that plant richness, composition and plant abundance greatly differed in their response according to the different levels of fire severity. We identified two distinct plant communities establishing along the fire severity gradient: one in the low severity areas (LS), where plant community had a rapid recovery immediately after fire, being more similar to the unburned forest (UN); and the other in the more fire-affected areas (MS and HS), where the plant community was significantly different from the UN. Interestingly, plant composition in the HS and MS increased in the following years after fire, becoming more similar with the UN over time. Regarding the establishment of non-native species, the abundance of these in HS and MS was low in the first year, with a slight increase in MS areas in the next years (2017 and 2018). This suggest that the fire itself is not a direct mediator for the establishment of non-native species. On the contrary, non-natives were far more abundant in LS areas, which reinforces the hypothesis that the establishment of non-native species are also favored by cattle activity. Cattle had a great effect on plant communities after fire, mainly due to the selection of palatable species (e.g., C. culeou), which prompted higher abundances of less palatable species (e.g., B. microphylla).

Our results also revealed the heavy impact of fire on the dominant trees A. araucana and N. pumilio. The former had better autoecological characteristics to survive fires of low-to-moderate severity. However, N. pumilio was significantly affected by severe fires, with no establishment after fire in HS areas (not even a single individual), nor during the three years of evaluation. Our findings also imply a potential compositional change in the forest if restoration actions are not considered. At this point, two management actions could be recommended: a) the exclusion of cattle within fire-affected areas to decrease their impact on vegetation recovery, and b) afforestation with 
N. pumilio in high fire severity areas, due to its unsuccessful recruitment after fire. This research constitute one of the first attempts to understand the early dynamic of plant communities in Araucaria-Nothofagus forests after a severe wildfire, and provides insights in how plant communities can recover after fire and should be considered for designing and implementing restoration strategies for burned Araucaria-Nothofagus forests.

\section{Supplementary information}

Supplementary information accompanies this paper at https://doi.org/10 1186/s40663-019-0202-2.

Additional file 1. Geographic location, altitude and aspect for each permanent sample plot established along a fire severity gradient within old-growth Araucaria-Nothofagus forests in the National Reserve China Muerta, La Araucanía region, south-central Chile.

Additional file 2. Floristic catalog of the vegetation found in oldgrowth Araucaria-Notofagus forests three years after fire in the National Reserve China Muerta, in the Andes of south-central Chile.

\section{Acknowledgements}

We thank J. Urrutia-Estrada, M. Barrientos, N. Muñoz, F. Pérez, A. del Fierro and the park rangers from the National Reserve China Muerta for their help with fieldwork. Two peer reviewers made a number of suggestions greatly improving the paper.

\section{Authors' contributions}

PAV collected data, performed statistical analyses and drafted the manuscript. AFR designed the study, collaborated with fieldwork and helped to write the manuscript. BM collaborated with data analysis. AP helped to write the final draft and collaborated with interpretation of results. All authors revised and approved the final manuscript draft.

\section{Funding}

This research was funded by Fondo Nacional de Desarrollo Científico y Tecnológico, FONDECYT 11150487. PAV thanks to the Erasmus+ Program for funding a research internship at the Division of Forest, Nature and Landscape, KU Leuven, Belgium. AP was funded by CONICYT AFB-170008. AFR is supported by Concurso Nacional Inserción en la Academia 2017 CONICYT-PAI 79170054.

\section{Availability of data and materials}

Available on request.

\section{Ethics approval and consent to participate}

Not applicable.

\section{Consent for publication}

Not Applicable.

\section{Competing interests}

The authors declare that they have no competing interests.

\footnotetext{
Author details

${ }^{1}$ Laboratorio de Biometría, Departamento de Ciencias Forestales, Universidad de La Frontera, Casilla 54-D, Temuco, Chile. ${ }^{2}$ Programa de Magíster en Manejo de Recursos Naturales, Facultad de Ciencias Agropecuarias y Forestales, Universidad de La Frontera, Casilla 54-D, Temuco, Chile. ${ }^{3}$ Butamallin Research Center for Global Change, Universidad de La Frontera, Temuco, Chile. ${ }^{4}$ Instituto de Ecología y Biodiversidad (IEB), Santiago, Chile. ${ }^{5}$ Department of Earth and Environmental Sciences, University of Leuven, Celestijnenlaan 200E, Box 2411, 3001 Leuven, Belgium. 'aboratorio de Invasiones Biológicas (LIB), Facultad de Ciencias Forestales, Universidad de Concepción, Casilla 160-C, Concepción, Chile.
}

Received: 29 April 2019 Accepted: 24 September 2019

Published online: 18 October 2019

\section{References}

Aagesen DL (1998) Indigenous resource rights and conservation of the monkeypuzzle tree (Araucaria araucana, Araucariaceae): a case study from southern Chile. Econ Bot 52:146-160. https://doi.org/10.1007/BF02861203

Bates D, Maechler M, Bolker B, Walker S (2015) Fitting linear mixed-effects models using Ime4. J stat Softw 67(1):1-48. https://doi.org/10.18637/jss.v067.i01

Bekker MF, Taylor AH (2010) Fire disturbance, forest structure, and stand dynamics in montane forests of the southern cascades, Thousand Lakes wilderness, California, USA. Ecoscience 17(1):59-72. https://doi.org/10.1080/ 17550874.2013 .816800

Blackhall M, Raffaele E, Veblen TT (2008) Cattle affect early post-fire regeneration in a Nothofagus dombeyi - Austrocedrus chilensis mixed forest in northern Patagonia, Argentina. Biol Conserv 141:2251-2261. https://doi.org/10.1016/j. biocon.2008.06.016

Blair DP, McBurney LM, Blanchard W, Banks SC, Lindenmayer DB (2016) Disturbance gradient shows logging affects plant functional groups more than fire. Ecol Appl 26:2280-2301. https://doi.org/10.1002/eap.1369

Bond WJ, van Wilgen BW (1996) Surviving fires - vegetative and reproductive responses. In: Bond WJ, van Wilgen BW (eds) Fire and plants, 1st edn. Chapman \& Hall, London, pp 34-51. https://doi.org/10.1007/978-94-0091499-5

Bowman DMJS, Balch JK, Artaxo P, Bond WJ, Carlson JM, Cochrane MA, D'Antonio CMD, DeFries RS, Doyle JC, Harrison SP, Johnston FH, Keeley JE, Krawchuk MA, Kull CA, Marston JB, Moritz MA, Prentice IC, Roos Cl, Scott AC, Swetnam RW, van der Werf GR, Pyne SJ (2009) Fire in the earth system. Science 324:481-484. https://doi.org/10.1126/science.1163886

Burns BR (1993) Fire-induced dynamics of Araucaria araucana - Nothofagus antarctica forest in the southern Andes. J Biogeogr 20:669-685. https://doi. org/10.2307/2845522

Center for Information of Natural Resources - CIREN (2010) Determination of the current and potential soil erosion risk in Chile. Santiago, Chile, p 145

Chuong J, Huxley J, Spotswood EN, Nichols L, Mariotte P, Suding KN (2016) Cattle as dispersal vectors of invasive and introduced plants in a California annual grassland. Rangeland Ecol Manag 69(1):52-58. https://doi.org/10.1016/j.rama. 2015.10.009

Clarke KR (1993) Non-parametric multivariate analyses of change in community structure. Aust J Ecol 18:117-143. https://doi.org/10.1111/j.1442-9993.1993. tb00438.x

Cóbar-Carranza AJ, García RA, Pauchard A, Peña E (2014) Effect of Pinus contorta invasion on forest fuel properties and its potential implications on the fire regimes of Araucaria araucana and Nothofagus Antarctica forests. Biol Invasions 16(11):2273-2291. https://doi.org/10.1007/s10530-014-0663-8

Connel JH (1978) Diversity in tropical rain forests and coral reefs. Science 199 : 1302-1310. https://doi.org/10.1126/science.199.4335.1302

De Caceres M, Legendre P (2009) Associations between species and groups of sites: indices and statistical inference. Ecology 90:3566-3574. https://doi.org/ 10.1890/08-1823.1

De Paz M, Raffaele E (2012) Cattle change plant reproductive phenology, promoting community changes in a post-fire Nothofagus forest in northern Patagonia, Argentina. J Plant Ecol 6:459-467. https://doi.org/10. 1093/jpe/rtt004

dos Reis MS, Ladio A, Peroni N (2014) Landscapes with Araucaria in South America: evidence for a cultural dimension. Ecol Soc 19(2):43. https://doi.org/ 10.5751/ES-06163-190243

Fajardo A, González ME (2009) Replacement patterns and species coexistence in an Andean Araucaria-Nothofagus forest. J Veg Sci 20:1176-1190. https://doi. org/10.1111/j.1654-1103.2009.01117.x

Fuentes N, Sánchez P, Pauchard A, Urrutia J, Cavieres L, Marticorena A (2014) Invasive plants in south-Central Chile: a field guide. Laboratoy of biological invasions (LIB), Concepción, Chile, p 276

Fuentes-Ramirez A, Arroyo P, Del Fierro A, Pérez F (2019) Post-fire response of Araucaria araucana (Mol.) K. Koch: assessment of vegetative resprouting, seed production and germination. Gayana Bot 76:119-122. https://doi.org/10. 4067/S0717-66432019000100119

Fuentes-Ramirez A, Barrientos M, Almonacid L, Arriagada-Escamilla C, Salas-Eljatib C (2018) Short-term response of soil microorganisms, nutrients and plant recovery in fire-affected Araucaria araucana forests. Appl Soil Ecol 131:99106. https://doi.org/10.1016/j.apsoil.2018.08.010 
Fuentes-Ramirez A, Pauchard A, Hauenstein E (2011) Floristic composition of Andean grassland in alto bio-bio National Reserve (Lonquimay-Chile) and its relationship with the grazing regimen. Gayana Bot 68:28-39. https://doi.org/ 10.4067/S0717-66432011000100004

Gajardo R (1994) The natural vegetation of Chile. In: Classification and geographical distribution. Editorial Universitaria Press, Santiago, Chile

Garreaud RD, Alvarez-Garreton C, Barichivich J, Boisier JP, Christie D, Galleguillos M, LeQuesne C, McPhee J, Zambrano-Bigiarini M (2017) The 2010-2015 megadrought in Central Chile: impacts on regional hydroclimate and vegetation. Hydrol Earth Syst Sc 21:6307-6327. https:/doi.org/10.5194/hess21-6307-2017

González ME, Gomez-Gonzalez S, Lara A, Garreaud R, Diaz-Hormazabal I (2018) The 2010-2015 Megadrought and its influence on the fire regime in central and south-Central Chile. Ecosphere 9:e02300. https://doi.org/10.1002/ecs2. 2300

González ME, Lara A (2015) Large fires in the Andean Araucaria forests: when a natural ecological process becomes a threat. Oryx 49:389-395. https://doi. org/10.1017/S0030605315000599

González ME, Szejner M, Muñoz AA, Silva J (2010) Catastrophic fires in the Andean Araucaria-Nothofagus forests: effects of fire severity and vegetation response. Native Forest J 46:12-17

González ME, Veblen TT (2007) Wildfire in Araucaria araucana forests and ecological considerations about salvage logging in areas recently burned. Rev Chil Hist Nat 80:243-253. https://doi.org/10.4067/S0716078X2007000200009

González ME, Veblen TT, Sibold I (2005) Fire history of Araucaria-Nothofagus forests in Villarrica National Park, Chile. J Biogeogr 32:1187-1202. https://doi. org/10.1111/j.1365-2699.2005.01262.x

González ME, Veblen TT, Sibold J (2010) Influence of fire severity on stand development of Araucaria-Nothofagus pumilio stands in the Andean cordillera of south-Central Chile. Austral Ecol 35:597-615. https://doi.org/10. 1111/j.1442-9993.2009.02064.x

Grissino-Mayer HD, Swetnam TW (2000) Century-scale climate forcing of fire regimes in the American southwest. Holocene 10:213-220

Keeley JE (2012) Ecology and evolution of pine life histories. Ann For Sci 69:445453. https://doi.org/10.1007/s13595-012-0201-8

Key CH, Benson NC (1999) Measuring and remote sensing of burn severity: the CBI and NBR. In: Neuenschwander LF, Ryan KC (eds) Proceedings joint fire science conference and workshop. University of Idaho and International Association of Wildland Fire

Kottek M, Grieser J, Beck C, Rudolf B, Rubel F (2006) World map of the KöppenGeiger climate classification updated. Meteorol Z 15:259-263. https://doi.org/ 10.1127/0941-2948/2006/0130

Lara A, Solari ME, Rutherford P, Thiers O, Trecaman R (1999) Technical report in: coverage of the original vegetation in forests of the Valdivian Ecoregion around 1550 in Chile. Universidad Austral de Chile and World Wildlife Foundation, pp 32

Lenth R (2019) Estimated marginal means, aka least-squares means. R package version 1.3.5.1. https://CRAN.R-project.org/package $=$ emmeans.

Li C, Barclay H, Liu J, Campbell D (2005) Simulation of historical and current fire regimes in Central Saskatchewan. Forest Ecol Manag 208:319-329. https:// doi.org/10.1016/j.foreco.2005.01.001

Matthei O (1995) Handbook of the weeds that grow in Chile. Alfabeta Press, Santiago, Chile

McCune BP, Grace JB (2002) Analysis of ecological communities. MjM Software Design, Oregon, USA

McWethy DB, Pauchard A, Garcia RA, Holz A, González MM, Veblen TT, Stahl J, Currey B (2018) Landscape drivers of recent fire activity (2001-2017) in southCentral Chile. PlosOne 13(8):e0205287. https://doi.org/10.1371/journal.pone. 0201195

Minor J, Falk DA, Barron-Gafford GA (2017) Fire severity and regeneration strategy influence shrub patch size and structure following disturbance. Forests 8:221. https://doi.org/10.3390/f8070221

Mora M, Crisóstomo R (2016) Forest fires: under the eye of remote sensing. In: Technical report № 383, Revista Chile Forestal. Chilean Forest Service (CONAF), Santiago, Chile, p 62

Mundo IA, Kitzberger T, Roig Juñent FA, Villalba R, Barrera MD (2013) Fire history in the Araucaria araucana forests of Argentina: human and climate influences. Int J Wildland Fire 22:194-206. https://doi.org/10.1071/WF11164

Oksanen J, Blanchet FG, Friendly M, Kindt R, Legendre P, McGlinn D, Minchin PR, O'Hara RB, Simpson GL, Solymos P, Stevens MHH, Szoecs E, Wagner H (2018)
Vegan: community ecology package. R package version 2.4-6. https://CRAN. R-project.org/package=vegan

Paritsis J, Veblen TT, Holz A (2015) Positive fire feedbacks contribute to shifts from Nothofagus pumilio forests to fire-prone shrublands in Patagonia. J Veg Sci 26:89-101. https://doi.org/10.1111/jvs.12225

Pauchard A, Alaback PB (2004) Influence of elevation, land use, and landscape context on patterns of alien plant invasion along roadsides in protected areas of south-Central Chile. Conserv Biol 18:238-248. https://doi.org/10. $1111 / j .1523-1739.2004 .00300 . x$

Pickett STA, Thompson JN (1978) Patch dynamics and the design of nature reserves. Biol Conserv 13:27-37. https://doi.org/10.1016/0006-3207(78)90016-2

Pickup M, Wilson S, Freudenberger D, Nicholls N, Gould L, Hnatiuk S, Delandre J (2013) Post-fire recovery of revegetated woodland communities in SouthEastern Australia. Austr Ecol 38:300-312. https://doi.org/10.1111/j.1442-9993. 2012.02404.x

Puntieri J, Raffaele E, Martinez P, Barthelemy D, Brion C (1999) Morphological and architectural features of young Nothofagus pumilio (Poepp. \& Endl.) Krasser (Fagaceae). Bot J Linn Soc 130:395-410. https://doi.org/10.1111/j.1095-8339. 1999.tb00529.x

R Core Team (2019) R: a language and environment for statistical computing. $R$ Foundation for Statistical Computing, Vienna. https://www.R-project.org/.

Raffaele E, Veblen $\Pi$ (1998) Facilitation by nurse shrubs of resprouting behavior in a post-fire shrubland in northern Patagonia, Argentina. J Veg Sci 9:693698. https://doi.org/10.2307/3237287

Raffaele E, Veblen TT, Blackhall M, Tercero-Bucardo N (2011) Synergistic influences of introduced herbivores and fire on vegetation change in northern Patagonia, Argentina. J Veg Sci 22:59-71. https://doi.org/10.1111/j.1654-1103. 2010.01233.x

Reilly MJ, Wimberly MC, Newell CL (2006) Wildfire effects on plant species richness at multiple spatial scales in forest communities of the southern Appalachians. J Ecol 94:118-130. https://doi.org/10.1111/j.1365-2745.2005. 01055.x

Reyer CPO, Brouwers N, Rammig A, Brook BW, Epila J, Grant RF, Holmgren M, Langerwisch F, Leuzinger S, Lucht W, Medlyn B, Pfeifer M, Steinkamp J, Vanderwel MC, Verbeeck H, Villela DM (2015) Forest resilience and tipping points at different spatio-temporal scales: approaches and challenges. J Ecol 103:5-15. https://doi.org/10.1111/1365-2745.12337

Ross KA, Fox BJ, Fox MD (2002) Changes to plant species richness in forest fragments: fragment age, disturbance and fire history may be as important as area. J Biogeogr 29:749-765. https://doi.org/10.1046/j.1365-2699.2002.00722.x

Rossi JP (2011) Rich: an R package to analyze species richness. Diversity 3(1):112120. https://doi.org/10.3390/d3010112

Rumball W, Claydon RB, Forde MD (1990) "Grasslands muster" pasture browntop (Agrostis capillaris L. syn. A. tenuis Sibth.). New Zeal J Agr Res 33:335-337. https://doi.org/10.1080/00288233.1990.10428426

Sanguinetti J, Kitzberger (2010) Factors controlling seed predation by rodents and non-native Sus scrofa in Araucaria araucana forests: potential effects on seedling establishment. Biol Invas 12:689-706. https://doi.org/10.1007/ s10530-009-9474-8

Seidl R, Thom D, Kautz M, Martin-Benito D, Peltoniemi M, Vacchiano G, Wild J, Ascoli D, Petr M, Honkaniemi J, Lexer MJ, Trotsiuk V, Mairota P, Svoboda M, Fabrika M, Nagel TA, Reyer CPO (2017) Forest disturbances under climate change. Nature 7:395-402. https://doi.org/10.1038/nclimate3303

Stoddard MT, Huffman DW, Fulé PZ, Crouse JE, Sánchez AJ (2018) Forest structure and regeneration responses 15 years after wildfire in a ponderosa pine and mixed-conifer ecotone, Arizona, USA. Fire Ecol 14:12. https://doi. org/10.1186/s42408-018-0011-y

Sugihara NG, van Wagtendonk JW, Fites-Kaufman J (2006) Fire as an ecological process. In: Sugihara NG, Wagtendonk JWV, FitesKaufman J, Shaffer KE, Thode AE (eds) Fire in California's ecosystems. University of California Press, Berkeley, pp 58-74

Teillier S, Marticorena A, Macaya J, Bonnemaison C, Delaunoy J (2014) Flora of the Huilo Huilo biological reserve. A guide for species identification. Volume I, II y III. Huilo Huilo Fundation, Santiago, Chile, pp 343, 373, 473

Úbeda X, Sarricolea P (2016) Wildfires in Chile: a review. Global Planet Change 146:152-161. https://doi.org/10.1016/j.gloplacha.2016.10.004

Urrutia-Estrada J, Fuentes-Ramirez A, Hauenstein E (2018) Differences in floristic composition of Araucaria-Nothofagus forests affected by distinct fire severities. Gayana Bot 75:625-638

Veblen TT, Kitzberger T, Raffaele E, Lorenz DC (2003) Fire history and vegetation changes in northern Patagonia, Argentina. In: Veblen TT, Baker WL, 
Montenegro G, Swetnam TW (eds) Fire and climatic change in temperate ecosystems of the Western Americas, vol 160. Springer, New York, pp 265295. https://doi.org/10.1007/0-387-21710-X_9

Veblen TT, Kitzberger T, Raffaele E, Mermoz M, González ME, Sibold J, Holz A (2008) The historical range of variability of fires in the Andean-Patagonian Nothofagus forest region. Int J Wildland Fire 17:724-741. https://doi.org/10 1071/WF07152

Veblen TT, Kitzberger T, Villalba R (2005) Nuevos paradigmas en ecología y su influencia sobre el conocimiento de la dinámica de los bosques del sur de Argentina y Chile. In: Frangi J, Brown A (eds) Ecología y manejo de los bosques de Argentina. Editorial de la Universidad Nacional de La Plata, Argentina

Veblen TT, Mermoz M, Martin C, Kitzberger T (1992) Ecological impacts of introduced animals in Nahuel Huapi National Park, Argentina. Conserv Biol 6: 71-83. https://doi.org/10.1046/j.1523-1739.1992.610071.x

Whelan RJ (1995) The ecology of fire. Cambridge University Press, Cambridge, Cambridge Studies in Ecology

Zamorano-Elgueta C, Cayuela L, González-Espinosa M, Lara A, Parra-Vásquez MR (2012) Impacts of cattle on the south American temperate forests: challenges for the conservation of the endangered monkey puzzle tree (Araucaria araucana) in Chile. Biol Conserv 152:110-118. https://doi.org/10.1016/j. biocon.2012.03.037

\section{Submit your manuscript to a SpringerOpen ${ }^{\circ}$ journal and benefit from:}

- Convenient online submission

- Rigorous peer review

- Open access: articles freely available online

- High visibility within the field

- Retaining the copyright to your article

Submit your next manuscript at $\boldsymbol{\nabla}$ springeropen.com 